\title{
Towards Descriptive Adequacy of Cyberbullying: Interdisciplinary Studies on Features, Cases and Legislative Concerns of Cyberbullying
}

\author{
Youping $\mathrm{Xu}^{1}$ (D) Paula Trzaskawka ${ }^{2}$ (D)
}

Accepted: 23 June 2021 / Published online: 3 July 2021

(c) The Author(s), under exclusive licence to Springer Nature B.V. 2021

\begin{abstract}
In view of the complexity of cyberbullying, this paper aims to address the linguistic and legal aspects of cyberbullying from an interdisciplinary perspective. Based on authentic data collected from real cases, we will expound on features, defining properties and legal remedies of cyberbullying in the countries that contribute to this special issue, such as Nigeria, France, Poland and China. Firstly, we will present an overview of cyberbullying and its definition, along with cyberbullying's attributes. Next, we will cover the various forms of cyberbullying, such as hate speech, harassment and trolling. Each of these forms of cyberbullying result in numerous outcomes, many of which are serious and, in the worst case, can result in a victim's death. A discussion of such consequences and the legal remedies for cyberbullying will be provided. On a final note, the contributors seek to enrich the forthcoming studies on cyberbullying by offering suggestions towards descriptive adequacy of cyberbullying.
\end{abstract}

Keywords Cyberbullying · Definition $\cdot$ Hate speech $\cdot$ Legislation $\cdot$ Legal remedy

Cyber bullies can hide behind a mask of anonymity online, and do not need direct physical access to their victims to do unimaginable harm. https://blog.girlscouts. org/2013/04/anna-maria-chavez-confronting-cyber.html [accessed on 18.06.2021]

Anna Maria Chavez

Chief Executive Officer of U.S. Girl Scouts

Paula Trzaskawka

paula.trzaskawka@amu.edu.pl

Youping $\mathrm{Xu}$

xuyouping003@aliyun.com

1 Guangdong University of Foreign Studies, Guangzhou, People's Republic of China

2 Adam Mickiewicz University, Poznań, Poland 


\section{Introduction}

The last decades have witnessed the remarkable development of the Information Communication Technology (ICT), the prosperity of social media platforms in particular. However, while people harvest the convenience and freedom of online communication, some are haunted by cyberbullying. For example, one of the authors of this editorial introduction was bullied online and flooded with hate speech when she uploaded a video on TikTok in Poland. Even though she received support and comfort from her family and decided not to read and reply to those negative and harmful comments, offensive words, which were like punches in her face, are still remembered. Statistic data show that teenagers are the most vulnerable group of people who tend to experience cyberbullying [13], but as a matter of fact, even adults can also be reduced to victims of cyberbullying [24].

In 2019, Wagner postulates a theory for E-communication and E-victimization [42]. Taking cyberbullying as an example, she explores the triadic relationships among the victim, the perpetrator and the media facilitator, and takes anonymity, exposure, frequency and insecurity as indicators to analyse cyberbullying crimes and assess harm done to victims. It is noticed that "emojis express what words cannot say, as they are universal, save space and time, and most importantly capture the attention of the sender's audience. The shorter the messages, the more powerful, more visible, and the more attractive the messages are for the recipients" [42]. In 2020, the first issue devoted to E-discourse aggressiveness was published in the journal Social Semiotics (Volume 30, Issue 3, 2020). It was the first attempt to gather global information about the phenomenon of cybercrimes and cyberbullying. Interesting findings have been found, such as emotional features of emojis [40], conflicting functions of emojis on gender equality and sexual discrimination, and on forest protection [28], and aggressiveness of emojis in law [6, 43]. These studies are dedicated to the features, functions and consequences of emojis used in cyberbullying. Little attention has yet been paid to language of cyberbullying, the primary carrier of meaning, and to legal remedies of cyberbullying.

Chomsky [7] once mentioned that linguistic analysis is supposed to be adequate at three levels: observational adequacy, descriptive adequacy and explanatory adequacy. In view of the current research on cyberbullying, particularly the fact that there is no consensus on the definition of cyberbullying, it is vital for linguists to dig deeper and work towards the second level of adequacy. And this is where linguists can contribute the most to this topic. Contributors of this special issue, by drawing on authentic linguistic data and real cases from different parts of the world (such as Nigeria, Poland, France and China), analyse cyberbullying from an interdisciplinary perspective and intend to explore more fundamental issues, including but not limited to: its defining attributes and distinct linguistic patterns. Others focus on legal issues including the necessity to introduce new legislation regulating cyberbullying and available legal remedies for its victims. In the following sections, the defining properties, forms, consequences and legislative concerns of cyberbullying will be discussed, the main ideas and major findings of this Special Issue will be introduced, and suggestions for further research will be put forward. 


\section{Definition and Defining Properties of Cyberbullying}

There exist many definitions of cyberbullying, but one of the most common states that cyberbullying is "an aggressive, intentional act or behaviour that is carried out by a group or an individual, using electronic forms of contact, repeatedly and over time against a victim who cannot easily defend him or herself" [30]. National Crime Prevention Council claims that "Cyberbullying is similar to other types of bullying, except it takes place online and through text messages sent to cell phones" [31]. Moreover, cyberbullying is also regarded as "the process of using the Internet, cell phones or other devices to send or post text or images intended to hurt or embarrass another person" [12]. Below we list definitions of cyberbullying used by contributors in this Special Issue.

In Nigeria, cyberbullying is defined as the "process of using the internet, cell phones or other devices to send or post text or images intended to hurt or embarrass another person". The word "cyberbullying" is often used interchangeably with "cyber stalking" and in fact as Adediran [1] observes, the Cybercrimes Act 2015 of Nigeria uses the word 'cyber stalking' to refer to any course of conduct directed at a specific person that would cause a reasonable person to feel fear. In Poland, the Polish Criminal Code amended in 2011 recognizes cyberbullying and stalking as a criminal offence. Currently, this offence is punishable under article 190a of Polish Criminal Code [29]. Pyżalski [36] further proposes 5 types of electronic aggression based on types of the victim, such as electronic aggression against celebrities and electronic harassment against group members. In France, cyberbullying is defined by Article 222-33-2-2 of the Criminal Code as follows:

The fact of harassing a person by repeated comments or behavior with the purpose or effect of degrading his or her living conditions resulting in an alteration of his or her physical or mental health is punishable by one year's imprisonment and a fine of $€ 15,000$ when these acts have resulted in a total work incapacity of less than or equivalent to eight days or have not led to any work incapacity. (Criminal Code, Article 222-33-2-2 [19]).

In China, there is no official definition proposed for cyberbullying per se. However, when students are involved, it is regarded as an online form of bullying and is regulated by relevant anti-bullying rules and regulations. In 2017, the Ministry of Education and other 10 competent departments issued the Measures for Strengthening the Comprehensive Treatment of Bullying Among Primary and Secondary School Students in 2017, and defined bullying as follows:

Bullying among primary and secondary school students refers to incidents taking place inside or outside the campus (including primary and secondary schools and secondary vocational schools) between or among students, with one party (an individual or a group of people) deliberately or maliciously conducting insults through physical, language or online methods for one or more times, resulting in the other party (individual or group) suffering from physical injury, property loss or mental distress. 
To sum up, cyberbullying is a form of bullying or harassment effected via electronic means and intends to do harm to the victims. Sometimes, the term "cyberbullying" is used interchangeably with "cyber harassment". Nevertheless, cyberbullying has its distinct features and defining properties. Sadly, it is found that except two shared properties, i.e., intent and repetition, scholars fail to reach a consensus even on the defining properties of cyberbullying, let alone its definition [46]. For example, Huston [22] regards electronic form of contact, an aggressive act, and harm of the victim as the other three core features of cyberbullying, while Ira-Katharina and Petermann [23] take power imbalance, direct and indirect cyberbullying and the victim's perception as other defining features of cyberbullying.

\section{Forms of Cyberbullying}

Cyberbullying behaviour includes posting rumours, threats, sexual remarks, revealing the victim's personal information, or pejorative labels including hate speech [8]. However, the distinction between the expressions of offence, hate speech and cyberbullying is often blurred. The problem in defining them unequivocally stems from the fact that cyberbullying is constantly evolving due to new tools and ways of attacking people online. The complexity of cyberbullying can be visible when the victim is not only harassed but also attacked verbally though comments posted on the internet.

One major form of cyberbullying is hate speech. There is a specific reason for the comparison of hate speech with cyberbullying at the same place. Most cyberbullies use hate speech to offend their victims. Hate speech is defined as a "public speech that expresses hate or encourages violence towards a person or group based on something such as race, religion, sex, or sexual orientation" [4]. Moreover, hate speech is "usually thought to include communications of animosity or disparagement of an individual or a group on account of a group characteristic such as race, colour, national origin, sex, disability, religion, or sexual orientation" [32].

The second form of cyberbullying is internet trolling [29]. It is a common form of cyberbullying and aims to evoke a reaction, cause disruption, gain personal amusement or even draw attention of the public [9, 11]. Trolling is present in social networking sites when a troll is provoking a response through the use of bad language, or even insults. Internet trolls spend time looking for heated discussion topics where they can attack somebody verbally. In most cases trolls act this way to feel better by making others feel bad.

The third form of cyberbullying may be cyber stalking which is "the transmission of any communication through the means of a computer to bully, threaten or harass another person where such communication places another person in fear of death, violence or bodily harm amounts to cyber stalking" [1]. Cyber stalking happens when a person is making real threats. Sometimes such threats may change their form from online into real life.

Exclusion, harassment and outing are other forms of cyberbullying. The first one, namely exclusion, is the deliberate act of leaving someone out and it may happen in different ways such as being excluded from friends' parties or activities, not being 
tagged in online conversations in group chats or a person may not use social networking sites at all and is being cyberbullied about it online by the peers. The second one, viz harassment, is a sustained, constant and intentional form of sending messages to a victim via a phone or the Internet. The third one, called outing, is a deliberate act of embarrassing or publicly humiliating somebody through the online posting of sensitive, private or embarrassing information without their consent [18].

There are other forms of cyberbullying which are fraping, creating fake profiles, dissing, trickery or catfishing. Fraping is a dangerous form of cyberbullying in which a bully is impersonating a victim and is posting in his/her name [44]. Dissing refers to the behaviour that one sends or posts cruel gossip or rumors about the other to damage the other's reputation or friendships with others [18]. A cyberbully may post photos, screenshots or videos to put somebody down and to draw one's attention to the fact that the cyberbullied is not a nice person. In this case, as with the previous one both harasser and the victim probably know each other very well. Another form of cyberbullying is trickery. A perpetrator gains the victim's trust so that he/ she reveals secrets or embarrassing information that then the perpetrator publishes online. Once the trust is gained, the perpetrator sends private information about the victim to a third party. The last form of cyberbullying known to the authors of this editorial is catfishing. Catfishing [26] is when "another person steals somebody's online identity, usually photos, and re-creates social networking profiles for deceptive purposes" [8]. Here, the identity of a cyberbully is also hidden. This person may steal some of the victim's photos and create an account with fake name and information or it may be other way round. Nevertheless, the good name or image of the person may be destroyed.

To sum up, cyberbullying may exist in various forms, with using hate speech, cyber harassment and cyberstalking as common forms. Due to its aggressive nature, some argues that "cyberbullying is another name for internet aggression" [25, 34] which are 'overt, intentional acts of aggression toward others online"" [47].

\section{Consequences of Cyberbullying}

It appears that consequences of cyberbullying vary a lot. It may be a disturbance to routine life, but can also be extremely harmful or even deadly. The contributors in this Special Issue provide us with many examples of fatal consequencese. In some of the reported cases, victims of cyberbullying have committed suicide as a result of fear or shame $[1,41]$.

According to the statistics provided by IPSOS 2018 online, harassment and bullying are now ubiquitous and widespread in modern societies. It is a worldwide phenomenon but in different regions of the world the numbers of cyberbullied and their bullies differ. For example, Latin America has the highest level of social media bullying, reaching 76\%. North America comes second at $67 \%$, followed closely by Europe at $65 \%$, the Middle East/Africa at 61\%, and the Asia Pacific at 53\%. As for specific countries, Peru is number one with the highest level of social media bullying at $80 \%$. Argentina comes second at $74 \%$, followed by Mexico (73\%), Brazil (70\%), Malaysia (71\%), Great Britain (69\%), Canada (68\%), and the USA (67\%). 
It is a well-known fact that when a person is being a target of cyberbullying, he/ she may have a higher tendency to abuse drugs or alcohol. Additionally, they will probably suffer emotional trauma and any other physical issues causing low selfesteem, anxiety, depression, delinquency or family problems. In cases of cyberbullying at school, a victim may have problems with grades or he/she may even avoid classes. The consequences to a person who is cyberbullying is not regulated thoroughly. For example, in the USA only 14 states impose criminal penalties. These penalties can include fines (as high as \$2500) or jail time (a year). When it comes to cyberbullying at school some school districts must include policies that will fight against such acts to be in compliance with current laws. the bully may be suspended. However, statistics can be terrifying. ${ }^{1}$ According to Ditch The Label 2018 the most negative impact on the cyberbullied person may be as follows:

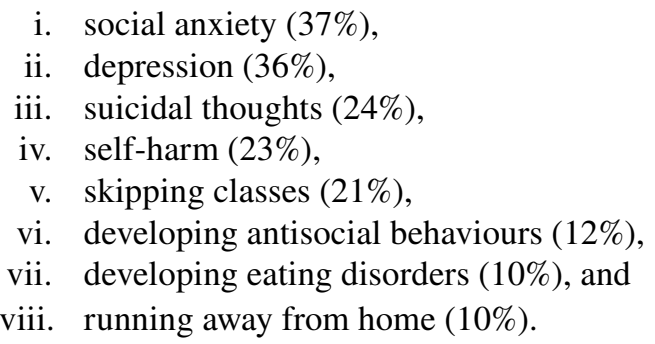

It appears that people of different age groups could be victims of cyberbullying. Not only middle and high school children but also adults as it is confirmed by examples given by the authors of this Special Issue [1, 41, 46]. One terrible thing is that cyberbullying seems to have gained normalcy: even though bullies are aware of the criminal connotation of their actions but feel no remorse because of the anonymity provided by the Internet in an unprecedented scale. The very fact that perpetrators do not need to face their victims makes them brazen.

\section{Concerns and Challenges in Legislating Cyberbullying}

In view of the severity of cyberbullying, such as the suicide of the American teenager Megan Meier in 2006 and the Canadian teenager Amanda Todd in 2012, many countries have taken a quick action to legislate cyberbullying. New acts are enacted or existing laws are amended. For example, statistics from https://cyberbullying.org/ bullying-laws show that by 2015 all states in America have some form of anti-bullying laws, most of which explicitly include cyberbullying in the legal provisions. In France, Article 222-33-2-2 of the Criminal Code was created in 2014 to define cyberbullying and set out the penalty [41]. In Poland, cyberbullying is punishable under Article 190a of the Polish Criminal Code effective as of 2011 [29]. In Nigeria,

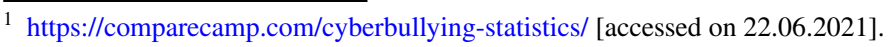


cyberbullying is expressly criminalized by the Cybercrime Act 2015, the Criminal Code Act and Penal Code Act [1]. In addition to the Cybersecurity Law, China also adds one article to the newly amended Law on the Protection of Minors in 2021 [41].

The report "Analysis of State Bullying Laws and Policies" released by the U.S. Department of Education in 2011 ("the Report" for short) finds that "Eighteen state laws include specific statutes addressing the rights of bullying victims to seek legal remedies under law" [39]. In fact, to make it clear that victims have the right to pursue other legal remedies, many state laws include provisions titled "victims' rights to redress". For example, the Oregon statute expressly asserts that the state law "may not be interpreted to prevent a victim of harassment, intimidation or bullying or a victim of cyberbullying from seeking redress under any other available law, whether civil or criminal" [39]. It is thus evident that legislators make great efforts to offer a legal shield to protect the victims of cyberbullying.

Despite these efforts, some scholars still show great concerns about the necessity and effectiveness of legislation to criminalize cyberbullying. For instance, Justin W. Patchin [35], a co-director of the Cyberbullying Research Center and criminal justice professor, confesses that, "I am not convinced that a state or federal law which criminalizes cyberbullying is necessarily the best approach". He argues that "The vast majority of all cyberbullying can be effectively handled informally... In the rare event that a cyberbullying incident rises to a level warranting criminal intervention, we already have existing laws which can be utilized (stalking, criminal harassment, felonious assault, etc.)." Apparently, the necessity of legislating cyberbullying is under question. Nevertheless, the assumption may be correct as some researchers point out that bullies are minors [27] and therefore there are limits to their penalization resulting from the fact that they have not attained the age of majority and may not have full comprehension of their deeds.

Besides, the effectiveness of legislation is also challenged. The Report [39] points out that "[t]he review of state bullying legislation reveals clear differences in the terms used to define bullying and harassment". As a matter of fact, it is found that the legislative language used in bullying laws are more often than not directly borrowed from harassment statutes, which may blur important legal distinctions between "bullying" and "harassment" [15]. It is thus not surprising that in the legal context, the use of inconsistent or even contradictory terms "sometimes contributes to confusion concerning how a specific incident should be treated" [39].

Several reasons may account for the above concerns for legislating cyberbullying. Firstly, a lack of a uniform definition of cyberbullying makes it hard to pin down the exact subject matter of the legislation. Ira-Katharina and Petermann [23] notice that scholars often tailor the definition of cyberbullying to their own study. They find that there are at least 24 new definitions on cyberbullying from 2012 to 2017, let alone previously proposed ones. Sadly, even the concept analysis of defining attributes of cyberbullying end with different results. As a result, little consensus has been achieved concerning the denotation of cyberbullying. However, there is the more complex reason that may be the root of inconsistency - different nations are sensitive to different types of massages. Thus, the same message may be considered humorous in one country while in another it may be damaging and bullying. The 
same rule applies to discriminatory actions and other types of harassment (e.g., sexual in the form of allusions or jokes).

Secondly, as an umbrella term of online aggressive behaviour, the connotation of cyberbullying remains quite vague. Doo et al. [14] find that definitions of cyberbullying are invariably connected either with the place where cyberbullying occurred or with the contents which cyberbullies used to cyberbullying victims. In other words, the "electronic forms of contact" [37], such as the use of e-mail, instant messaging, chat rooms, social media platforms and cell phones [20], set the scene for cyberbullying and make the term cyberbullying encompass almost everything that happens online. Apart from differences in various places of occurrence, a vast array of "the aggressive act" [22] of cyberbullying behaviour complicates the problem. Apart from the typologies presented above we may refer here to the categorization by Willard [45] who differentiates seven major types of cyberbullying behaviours: flaming, harassment, denigration, impersonation, outing and trickery, exclusion and cyberstalking. As a result, it is hard to pin down the boundaries of cyberbullying.

Thirdly, the tension between the attempt to protect the victims of cyberbullying and the right to free speech poses a further challenge to legislative attempts. On the one hand, people enjoy the fundamental human right to freely express themselves. This right is expressly provided by Article 19 of The Universal Declaration of Human Rights "Everyone has the right to freedom of opinion and expression; this right includes freedom to hold opinions without interference and to seek, receive and impart information and ideas through any media and regardless of frontiers." On the other hand, victims of cyberbullying are intimated or tormented by online aggressive speech, with some choosing to put an end to their own lives. As a result, cyberbullying cases may draw wider attention from the society than other cases and arouse more heated debates. The problem is the thin red line between the freedom of speech and freedom of expressing one's opinions and the act of cyberbullying (e.g., by hate speech). It turns out that delineating the borders of the freedom of speech and cyberbullying may be very subjective even in the course of enacting legislation and conducting trials.

Among others, the constitutionality of statutory laws on cyberbullying is one of the central issues to be decided by courts. Current rulings in America reveal that courts attach different degrees of importance to freedom of speech and cyberbullying. For example, the New York Court of Appeals invalidated Albany County's cyberbullying law in 2014 in People v. Marquan M. By contrast, in 2015, in State v. Bishop, the North Carolina Court of Appeals upheld North Carolina's cyberbullying statute and rejected Bishop's First Amendment challenge to the law. Despite disagreements among scholars and practitioners on the intersection between freedom of speech and cyberbullying, it is nevertheless apparent that cyberbullying is a "loaded term" [38] and problems brought by "the breadth and vagueness of the statutory language" on cyberbullying are to be solved [21].

To conclude, it has been a trend worldwide to legislate on cyberbullying. However, current challenges and debates on legislating cyberbullying have much to do with terms used to refer to cyberbullying acts and with statutory language defining cyberbullying. 


\section{Research Topics and Major Findings of This Special Issue}

In this special issue, contributors either focus on theoretical or practical problems of cyberbullying. We are interested in the following questions: How to define cyberbullying? and What can be done to improve research on cyberbullying? The first three papers show examples of cyberbullying through different social media towards different groups of people, such as hunters or foresters. The second group of papers deals with linguistic aspects of cyberbullying in China. The authors carry out their analyses with the usage of corpus linguistics tools.

Wagner points out that "Cyber bullying remains a nebulous concept that can be deciphered in many ways." [42] The first perspective is the theoretical perspective with regard to the mechanism of cyberbullying [41]. In their paper "Machiavellian Apparatus of Cyberbullying: Its Triggers Igniting Fury with Legal Impacts", Anne Wagner and Wei Yu discuss Machiavellian Apparatus which "proves to be sophisticated, given its powerful nature, and results in its victims being ensnared in a cyber net from which they see very little escape". They divide young netizens who are the most vulnerable to cyberbullying into the silent readers and the active readers, and differentiate three main types of online players, namely, the newbie, the troll and the flamer [42]. They examine the two triggers that expose the tyrannical mechanisms of such a discourse, which serve as power amplifiers for young netizens. Drawing on real cases, they illustrate how these power amplifiers ignite the fuse that triggers this social networking madness.

The second perspective may be based on laws and regulations unique to a particular country [1]. In his paper, "Cyberbullying in Nigeria: Examining the Adequacy of Legal Responses", Adediran examines the effectiveness of legal responses to cyberbullying in Nigeria. He finds that cyberbullying, particularly outing, trickery, trolling and roasting, is rampant in Nigeria. He notices that while in theory, most forms of cyberbullying can be prosecuted under the Cybercrimes Act, little notable enforcement of the law to prosecute cyberbullying has been documented. As a result, the author alleges that "the protection of image rights will go a long way to assist in curbing the act of cyberbullying in Nigeria" [1].

The third perspective focuses on communities which are especially frequently bullied or stereotypically perceived [28, 29]. In "I Would Kill the Director and Teachers in the School" Cyberbullying of Hunters in Poland, Matulewska and Gwiazdowicz [28] analyze online linguistic aggression towards hunters, in particular, the use of emotion-loaded language in shaping the image of hunters. They find that "people brought up in cities, far away from nature, are easily convinced to attack other groups which they perceive as deviant" [3]. Due to limited knowledge about nature and its laws, overly idealistic and naïve approach may easily lead to verbal and non-verbal aggression towards the community of hunters.

In another similar topic titled "Cyberbullying in Polish Debate on the Biatowieża National Forest”, Matulewska, Kic-Drgas and Trzaskawka [29] focus on hate speech concerning the opponents and proponents of the cut out of the Białowieża National Forest due to the attack of the bark beetle in Poland. 
Their analysis summarizes linguistic patterns of aggressive and vulgar statements. For example, they find out that there are four strategies of staging anger online, including offensive and sometimes vulgar language, irony, rhetorical questions, and using analogies and metaphors. Besides, the authors note that the shorter the comment is, the more vulgar and hateful it is.

Apart from the above mentioned three perspectives on cyberbullying, the second part of this Special Issue aims at analyzing the discourse of cyberbullying and depicting the scenario of cyberbullying in China. In The Invisible Aggressive Fist: Features of Cyberbullying Language in China, Youping Xu [46] presents lexical and syntactic features of cyberbullying language targeted at adults. Drawing on data from her corpus based on a high-profile defamation case arising out of cyberbullying in China, she argues that if we want to detect and identify cyberbullying through language more efficiently in the future, it is vital to find out: (a) how a group of people target at a victim; (b) how harm is inflicted intentionally to the victim in a repeated way; and (c) how the victim perceives the bullying. She finds that distinct features, such as a high density of the second personal pronoun "you" used to drag the victim into the face-to-face online interaction and an unconventional use of interrogative questions ending with exclamation marks to denounce the behaviour of the victim, will be helpful for further research on parameters in cyberbullying detection.

While $\mathrm{Xu}$ [46] shows interest in the civil dispute of a defamation case arising out of cyberbullying, Jinshi Chen is more concerned about criminal behaviors of cyberbullying. In his paper 'You are in trouble!' A Discursive Psychological Analysis of Threatening Language in Chinese Cellphone Fraud Interactions, Chen [5] analyses 20 pieces of cellphone conversations in the authentic fraud cases from Chinese media (together with the use of Praat 6.1.13). From the discursive psychological perspective, Chen analyzes how cellphone fraudsters construct their fake identities (police officers, procurators, telecom staff or gang leaders) through information gap and information sharing in their turn-taking designs. He finds that fraudsters use such conversational skills in a threatening tone as repetition, interruption, higher pitch and louder speech to trigger victims' psychological panic based on prepared and designed scripts. The findings of this paper will be conducive to the fight against fraudster' online threats and bullies.

The last paper From Flaming to Incited Crime: Recognising Cyberbullying on Chinese WeChat Account written by Shaomin Zhang [48] analyzes twenty-six suspicious Chinese online flaming articles concerning poisoning of dogs posted on the WeChat subscription account. Based on the Speech Act Theory, this quantitative corpus linguistic analysis of Keyness and semantic prosody (AntConc 3.5.7.) intends to find out the lexical, semantic and pragmatic manifestations of cyberbullying, explore how cyberbullying language hurts some readers by the writer's attitudinal meaning, and discuss typical linguistic items in the cyberbullying article that may incite unlawful action or wrongs. This study helps in penetrating and recognizing online flaming articles in Chinese social media and will provide references for protecting the mass audience from being victims. 


\section{Conclusion}

By June 20, 2021, the coronavirus (Covid-19) has caused over 3.8 million of deaths worldwide [17], with over 177 million confirmed cases in over 210 countries and regions. While the coronavirus disrupted the economy of the world, shattered the normal life of numerous families and brought pain to endless individuals, cyberbullying, an invisible "virus" also does great harm to society. According to the statistics from the i-SAFE foundation [16], a non-profit foundation whose mission is to "educate and empower youth to make their Internet experiences safe and responsible", over half of adolescents and teens have been bullied online, and about the same number have engaged in cyberbullying. Obviously, the infectious rate of cyberbullying is much higher than coronavirus. Sadly, while we are clear about the structure and properties of coronavirus and have vaccines, little consensus has even been reached as to the definition of cyberbullying. That is why Patchin [35] urges that "Legislators stop and work to develop a law that is reasonable, practical, constitutional, and informed by research." To this end, concerted efforts are to be made among a group of experts to identify the real issues going on in cyberbullying.

This Special Issue has been a pioneer to bring together linguists, law professors and forestry experts, addressing the issues of the definition, forms and legislative concerns of cyberbullying based on real cases in four countries through three continents. It covers a wide range of topics and presents the latest findings on cyberbullying. As a complex social phenomenon, we may have just touched a little bit of the corner of the iceberg and filled some research gaps. More joint efforts are expected to be made in the future to address the following issues:

\subsection{Linguistic Analysis of Interaction Among Various Participants}

Though cyberbullying takes on various forms, such as posting a picture or sharing a video, most of the bullying behaviors are executed through language. As a result, language will be the main and sometimes the sole evidence that records cyberbullying. While most of the current studies focus on the interaction between cyber bullies and victims, some have paid close attention to other participants in cyberbullying. According to Olweus [33], in the Bullying Circle, along with the students who bully and student who is bullied, there are bystanders who play six different roles in bullying. These roles fall on a continuum and are displayed in a U-shape, including Follower, Supporter, Passive Supporter, Disengaged On-looker, Possible Defender and Defender. Thus, to reveal the nature and features of cyberbullying, it is vital to analyze the interaction among these eight roles, including their participation framework, role play and role change.

\subsection{Construction of Large Corpora of Cyberbullying}

Computer sciences scholars who are interested in automatic cyberbullying detection primarily use English data collected from Twitter, MySpace and Formspring [46]. In this Special Issue, contributors construct their own small-scale corpus in 
French, English, Polish or Chinese. Their corpus-based study has enlarged the scope of language varieties to the existing literature, showing interesting language-specific and cultural-loaded linguistic patterns of cyberbullying. However, in the era of big data, it is vital to construct large corpora of cyberbullying centering on different languages and to conduct comparative studies. During the construction of such a large corpus, linguistic findings on cyberbullying are urgently needed in data collection, tagging and data analysis. Based on the corpus, the common features of cyberbullying could be found and candidate parameters to distinguish bulling and non-bullying language could be postulated.

\subsection{Semiotic Analysis of Cyberbullying Through Verbal and Nonverbal (e.g. images) Messages}

There is another threat around the corner as such channels of communication (social media) as TikTok, Instagram and others are the most popular platforms nowadays. Why is it a threat? The increasing popularity of such media is going to affect cyberbullying. There is huge possibility of bullying through posting pictures, photos, mems, movies of visual, audiovisual and verbal quality. As it was mentioned in the introduction of this Special Issue it is the fact that even one of the authors experienced this type of online hatred. However, bullying as such may happen also through movies or pictures rather than words. In today's world we have a tendency to make everything shorter and quicker. Attaching an emoji to a picture or a video can be only one example of this tendency. As it can be seen, the issue may be analyzed through different aspects and semiotic analysis of particular examples may prove that it is not only a one case study.

\subsection{Interdisciplinary Collaboration in Cyberbullying Detection and Prevention}

As a complicated social phenomenon, cyberbullying has aroused interest among sociologists, psychologists, linguists, law experts and computer scientists. While most scholars approach cyberbullying from their own field of expertise, some [27, $41]$ in this Special Issue) have started to explore cyberbullying from an interdisciplinary perspective. As advocated by Janet Ainsworth, President of International Association of Forensic Linguists and law professor of Seattle University, cross-fertilization is needed to nourish the research on language and law [2]. Hence, the collaboration between law experts and linguists is of great importance to cyberbullying, particularly in the drafting of bullying statutes. Besides, to effectively detect cyberbullying, it is urgent for computer scientists and linguists to cooperate with each other so as to lay down the linguistic conventions in data tagging and the extraction of distinctive linguistic features. Last but not the least, cooperation among educators, psychologists and linguists will undoubtedly be productive in terms of developing manuals and guidelines for cyberbullying prevention.

Cyberbullying is such a complex issue that joint efforts from different walks of life, such as researchers, educators, policy makers, school administrators, parents and Internet users, are urgently needed. This Special Issue is one of the first attempts 
where the authors provide some examples of cyberbullying towards specific groups from their countries of origin. Global approaches or global databases could broaden our legal and linguistic knowledge in the issue at hand and may allow us to take proper steps to combat cyberbullying. At present, joint efforts are expected to decipher cyberbullying so as to find out its defining features and reach a consensus on its definition. Only in this way can subsequently studies on the automatic detection of cyberbullying and effective prevention of cyberbullying make sense. This urgently call for interdisciplinary efforts made towards descriptive adequacy of cyberbullying.

\section{References}

1. Adediran, Adejoke. 2020. Cyberbullying in Nigeria: Examining the Adequacy of Legal Responses. International Journal for the Semiotics of Law. https://doi.org/10.1007/s11196-020-09697-7.

2. Ainsworth, Janet. 2020. The Use of Theory in Forensic Linguistics: A Plea for Methodological Cross-fertilization. Keynote speech delivered at the 11th Biennial Conference of China Association of Forensic Linguistics, Oct. 24-25, Shanghai, China.

3. Bartmiński, Jerzy, and Wojciech Chlebda. 2003. Problem konceptu bazowego i jego profilowaniana przykładzie polskiego stereotypu Europy. Etnolingwistyka 25: 69-95. https://doi.org/10.17951/et. 2013.25.69.

4. Cambridge Online Dictionary. Hate Speech. https://dictionary.cambridge.org/us/dictionary/english/ hate-speech. Accessed 24 January 2020.

5. Chen, Jinshi. 2020. 'You are in trouble!': a discursive psychological analysis of threatening language in Chinese cellphone fraud interactions. International Journal for the Semiotics of Law. https://doi.org/10.1007/s11196-020-09765-y.

6. Cheng, Le., Yuxiu Sun, and Jian Li. 2020. Aggressiveness of emojis before the court: a sociosemiotic iinterpretation. Social Semiotics 30 (3): 365-378. https://doi.org/10.1080/10350330.2020. 1731190.

7. Chomsky, Noam. 1965. Aspects of the Theory of Syntax. Cambridge, MA.: MIT Press.

8. Cyber Bullying Law and Legal Definition. USlegal.com. https://defnitions.uslegal.com/c/cyberbullying/. Accessed 20 January 2020.

9. Dagan, Maeve. 2014. 5 facts about online harassment. https://www.pewresearch.org/facttank/2014/ 10/30/5-facts-about-online-harassment/ Accessed 23 March 2020.

10. Devakunchari, Ramalingam, and Valliyammai Chinnaiah. 2018. Fake profile detection techniques in large-scale online social networks: a comprehensive review. Computers \& Electrical Engineering 65: 165-177.

11. Diaz, Fernando. 2016. Trolling \& the first amendment: protecting internet speech in the era of cyberbullies \& internet defamation. University of Illinois Journal of Law, Technology \& Policy 1: 135-160.

12. Ding, Lin, and Hua Hu. 2013. Feature Analysis of the Social Media. International Workshop on Computer Science in Sports: 186-190.

13. Djuraskovic, Ogi. 2021. Cyberbullying Statistics, Facts, and Trends (2021) with Charts. https://first siteguide.com/cyberbullying-stats/ Accessed on May 28, 2021.

14. Doo, Kyunghee, Jeong Yeo-ju, and Kim Kay-Hyon. 2012. Review paper about cyberbullying studies: definition and types of cyberbullying. Korea Journal of Counseling 13 (4): 1581-1607.

15. Greene, Michael, and Randy Ross. 2005. The Nature, Scope, and Utility of Formal Laws and Regulations that Prohibit School-Based Bullying and Harassment. Persistently Safe Schools 2005: The National Conference of the Hamilton Fish Institute on School and Community Violence. https:// njbullying.org/documents/HamFish2005final.pdf

16. Bullying Statistics. http://www.bullyingstatistics.org/content/cyber-bullying-statistics.html Accessed April 10, 2021.

17. WHO Coronavirus (COVID-19) Dashboard. https://covid19.who.int Accessed June 20, 2021. 
18. Forms of Cyberbullying. https://kids.kaspersky.com/10-forms-of-cyberbullying/ Accessed June 4, 2021.

19. Criminal Code. https://www.legifrance.gouv.fr/codes/article_lc/LEGIARTI000037289658/ Accessed March 20, 2021.

20. Huang, Yun-yin, and Chien Chou. 2010. An analysis of multiple factors of cyberbullying among junior high school students in Taiwan. Computers in Human Behavior 26: 1581-1590.

21. Hudson, David. 2016. Is Cyberbullying Free Speech? ABA Journal 102:18-19. https://www.jstor. org/stable/https://doi.org/10.2307/26515946

22. Hutson, Elizabeth. 2016. Cyberbullying in adolescence: a concept analysis. Advances in Nursing Science 39 (1): 60-70.

23. Ira-Katharina, Peter, and Franz Petermann. 2018. Cyberbullying: a concept analysis of defining attributes and additional influencing factors. Computers in Human Behavior 86: 350-366.

24. Kowalski, Robin M., Allison Toth, and Megan Morgan. 2018. Bullying and cyberbullying in adulthood and the workplace. The Journal of Social Psychology 158 (1): 64-81.

25. Law, Danielle, Jennifer Shapka, Shelley Hymel, Brent Olsona, and TerryWaterhouse. . 2012. The changing face of bullying: an empirical comparison between traditional and internet bullying and victimization. Computers in Human Behavior 28: 226-232.

26. Lovelock, Michael. 2017. Catching a catfish: constructing the "good" social media user in reality television. Television \& New Media 18 (3): 203-217. https://doi.org/10.1177/1527476416662709.

27. Matulewska, Aleksandra, and Dariusz Gwiazdowicz. 2020. I would kill the director and teachers in the school cyberbullying of hunters in Poland. International Journal for the Semiotics of Law. https://doi.org/10.1007/s11196-020-09723-8.

28. Matulewska, Aleksandra, and Dariusz J. Gwiazdowicz. 2020. Cyberbullying in Poland: a case study of aggressive messages with emojis targeted at the community of hunters in urbanized society. Social Semiotics 30 (3): 379-395. https://doi.org/10.1080/10350330.2020.1731194.

29. Matulewska, Aleksandra, and Joanna Kic-DrgasPaulaTrzaskawka. 2020. Cyberbullying in Polish debate on the Białowieża national forest. International Journal for the Semiotics of Law. https://doi. org/10.1007/s11196-020-09750-5.

30. Moreno, Megan. 2014. Cyberbullying. JAMA Pediatrics 168 (5): 500. https://doi.org/10.1001/jamap ediatrics.2013.3343.PMID24791741.

31. National Crime Prevention Council. An Explanation of The Growing Phenomenon of Cyberbullying. https://www.ncpc.org/resources/cyberbullying/what-is-cyberbullying/. Accessed 12 January 2020.

32. Nockleby, John. 2000. Hate Speech. In Encyclopedia of the American constitution, ed. Leonard W. Levy and Kenneth L. Karst, 1277-1279. Detroit: Macmillan Reference US.

33. Olweus, Dan. 1993. Bullying at School: what we know and what we can do. Malden, MA: Blackwell Publishing.

34. Patchin, Justin, and Sameer Hinduja. 2006. Bullies move beyond the schoolyard: a preliminary look at cyberbullying. Youth Violence and Juvenile Justice 4 (2): 148-169.

35. Patchin, Justin. Cyberbullying Legislation. https://cyberbullying.org/cyberbullying-legislation. Accessed March 24, 2021.

36. Jacek, Py.żalski. 2011. Agresja elektroniczna wśród dzieci i młodzieży. Sopot: Gdańskie Wydawnictwo Pedagogiczne.

37. Smith, Peter, et al. 2008. Cyberbullying: its nature and impact in secondary school pupils. Journal of Child Psychology and Psychiatry 49 (4): 376-385.

38. Tucker, James. 2008. Free Speech and "Cyber-bullying". https://www.aclu.org/blog/free-speech/ free-speech-and-cyber-bullying. Accessed June 8, 2021.

39. U.S. Department of Education, Analysis of State Bullying Laws and Policies. Washington, D.C. 2011. http://www.ed.gov/about/offices/list/opepd/ppss/index.html. Accessed May 18, 2021.

40. Wagner, Anne, Sarah Marusek, and Yu. Wei. 2020. Sarcasm, the smiling poop, and e-discourse aggressiveness: getting far too emotional with emojis. Social Semiotics 30 (3): 305-311. https://doi. org/10.1080/10350330.2020.1731151.

41. Wagner, Anne, and Yu. Wei. 2021. Machiavellian apparatus of cyberbullying: its triggers igniting fury with legal impacts. International Journal for the Semiotics of Law. https://doi.org/10.1007/ s11196-021-09841-x.

42. Wagner, Anne. 2019. E-victimization and E-predation theory as the dominant aggressive communication: the case of cyber bullying. Social Semiotics 29 (3): 303-318. https://doi.org/10.1080/10350 330.2019.1587832. 
43. Wagner, Anne, Sarah Marusek, and Yu. Wei. 2020. Emojis and law: contextualized flexibility of meaning in cyber communication. Social Semiotics 30 (3): 396-414. https://doi.org/10.1080/10350 330.2020.1731198.

44. Moncur, Wendy, Kathryn Orzech, and Fergus Neville. 2016. Fraping, social norms and online representations of self. Computers in Human Behavior 63: 125-131. https://doi.org/10.1016/j.chb.2016. 05.042 .

45. Willard, Nancy. 2007. Cyber-Safe Kids, Cyber-Savvy Teens: Helping Young People Learn to Use the Internet Safely and Responsibly. Jossey-Bass.

46. Xu, Youping. 2020. The invisible aggressive fist: features of cyberbullying language in China. International Journal for the Semiotics of Law. https://doi.org/10.1007/s11196-020-09746-1.

47. Ybarra, Michele, and Kimberly Mitchell. 2004. Online aggressors/targets, aggressors, and targets: a comparison of associated youth characteristics. Journal of Child Psychology and Psychiatry and Allied Disciplines 45: 1308-1316. https://doi.org/10.1016/j.chb.2011.09.004.

48. Zhang, Shaomin. 2020. From flaming to incited crime: recognising cyberbullying on Chinese wechat account. International Journal for the Semiotics of Law. https://doi.org/10.1007/ s11196-020-09790-x.

Publisher's Note Springer Nature remains neutral with regard to jurisdictional claims in published maps and institutional affiliations. 